\title{
PENERAPAN PRINSIP KEBIJAKAN ZERO DELTA Q DALAM PEMBANGUNAN WILAYAH
}

\author{
Robertus Haryoto Indriatmoko \\ Pusat Teknologi Lingkungan, Badan Pengkajian dan Penerapan Teknologi (BPPT). \\ JIn. MH. Thamrin No.8 Jakarta Pusat. Gedung II Lt.20
}

\begin{abstract}
Principle of zero delta $Q$ policy is that a development should not increase water discharge to drainage system. Policy of zero delta $Q$ is apply to zone of recharge area and other zone which is not recharge area as well, because this area which is not as recharge area has contribute a great deal to local flood. Based on this therefore implemention of policy of zero delta $Q$ is applied to urban area such as Jakarta. Activities proposed for Jakarta were: 1. Optimize use of water reservoir, pond and site; 2. Implementation of artificial recharge or could be combined with biopore; 3 . Effective land use by provide open green areas; and 4. Normalization of drainage system.
\end{abstract}

Keywords : policy, zero delta q, flood, artificial recharge, biopore, development

\section{PENDAHULUAN}

Banjir tanggal 11 Februari 2002 mengejutkan banyak pihak sebab hampir $30 \%$ dari wilayah Jakarta tergenang air, transportasi lumpuh, dan terjadi korban jiwa akibat tanah longsor, tenggelam, hanyut dan tersengat aliran listrik. Total aliran air permukaan pada kejadian tersebut diperkirakan mencapai 70 juta meter kubik. Volume air yang sedemikian besar ini jelas tidak akan mampu ditampung oleh badan-badan sungai, situ atau waduk yang ada saat itu. Air telah meluap memasuki pemukiman yang dahulu merupakan dataran banjir sungai (floodplain area), sebagian tergenang di jalan raya sehingga menutup akses para pegawai yang akan memasuki kantor atau pabrik di wilayah tersebut.

Kejadian banjir serupa dengan tahun 2002, terjadi di tahun 2007. Lebih dari 60\% wilayah Jakarta terendam air (Gambar 1). Menurut laporan kejadian tersebut selain disebabkan oleh curah hujan yang tinggi juga dipicu oleh pasang di laut Jakarta. Menurut Badan Meteorologi, Klimatologi dan Geofisika (BMKG), pemantauan di 11 pos pengamatan hujan tercatat bahwa ratarata curah hujan mencapai $235 \mathrm{~mm}$, curah hujan tertinggi tercatat di stasiun klimatologi Pondok Betung yaitu $340 \mathrm{~mm}$. Curah hujan rata-rata sebesar $235 \mathrm{~mm}$ tersebut setara dengan curah hujan pada periode ulang 100 tahun pada probabilitas $20 \%$ (1).

Banjir telah mengakibatkan berbagai kerugian yang mengurangi kenyamanan mulai dari: transportasi/aksesibilitas, komunikasi, listrik, aktivitas perdagangan, jasa, kerusakan rumah, perkantoran dan roda perekonomian terganggu, bahkan harta benda dan nyawa. Pada tahun
2007, banjir telah menimbulkan kerugian dari sektor ekonomi hingga mencapai 4,3 Trilyun Rupiah, dan mengakibatkan 320.000 orang mengungsi selama lebih dari 10 hari dan 80 orang tewas. Pada tahun 2009 terjadi lagi banjir di Jakarta, kejadian yang paling parah adalah dengan jebolnya tanggul Situ Gintung, Cirende Tangerang. Meskipun banjir di tahun 2009 ini kondisi banjir tidak separah kejadian tahun 2007, namun terjadi jumlah korban yang lebih banyak. Ketika tanggul Situ Gintung jebol maka air waduk dengan volume $2.100 .000 \mathrm{~m}^{3}$ tumpah, akibatnya adalah 98 orang meninggal, menyebabkan 368 orang mengungsi, 102 orang hilang atau tengah dicari kerabatnya dan 319 rumah dinyatakan rusak. Berdasarkan catatan dari BMKG intensitas hujan saat itu adalah $200 \mathrm{~mm}$ dalam 2 jam. Tanggul Situ Gintung yang sebenarnya telah dilaporkan bocor dan terkikis itu akhirnya jebol(2) (Gambar 2).

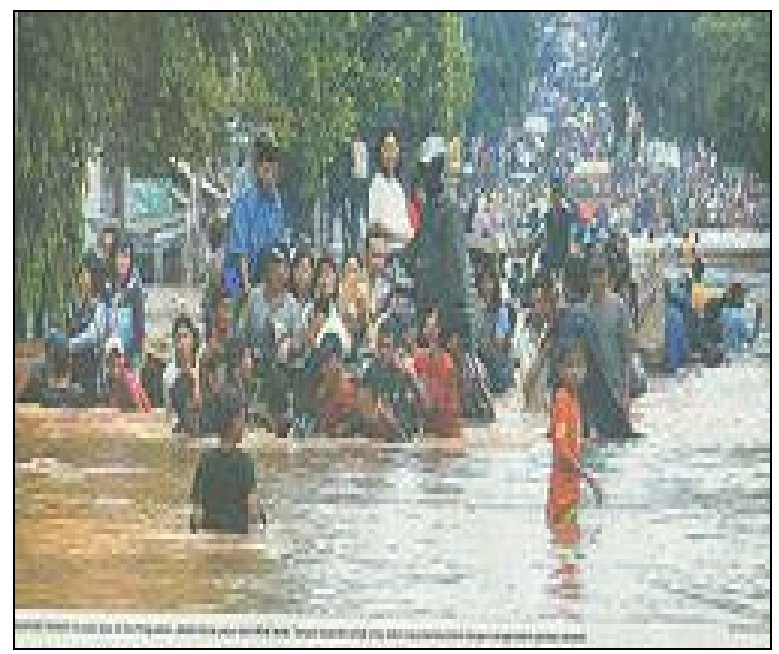

Gambar 1. Situasi Banjir di Jakarta (1) 


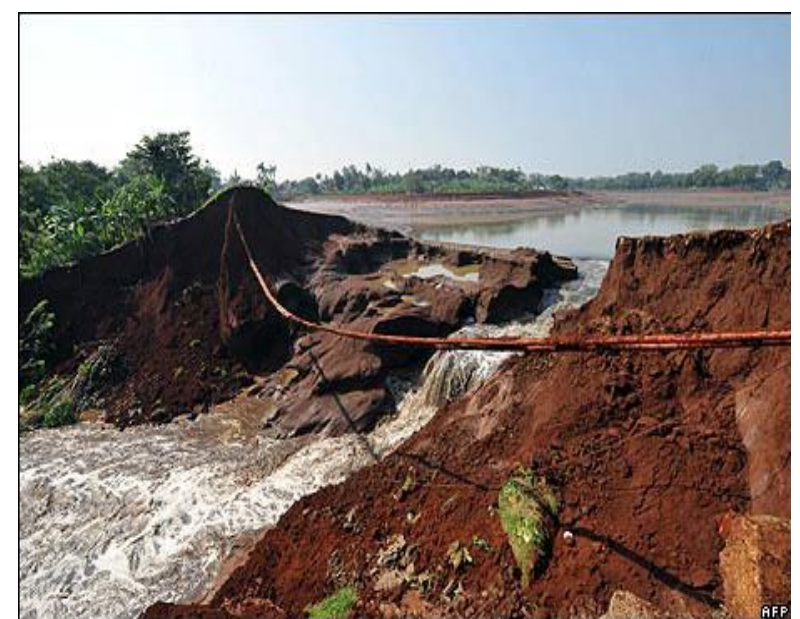

Gambar 2. Bendung Situ Gintung Jebol (1)

Perubahan pengunaan lahan, curah hujan, pendangkalan saluran atau sungai oleh sampah serta naiknya muka laut akibat terjadinya pasang surut, diduga merupakan penyebab utama banjir di Jakarta selama ini. Pernyataan tersebut didukung oleh hasil penelitian yang dilakukan di wilayah yang sedang berkembang bahwa akibat dari aktivitas pembangunan dan perubahan penggunaan lahan, akan menyebabkan dampak langsung dengan memberikan pengaruh utama pada sungai yang berupa (3) :

1. Debit air meningkat. Banjir yang berlangsung secara berulang-ulang dengan periode ulang 1 tahun, debit sungai meningkat sampai dengan tiga kali.

2. Volume aliran sungai bisa meningkat lebih dari dua kali, meskipun volume aliran juga ditentukan oleh tipe tanah dan kondisi hidrogeologinya.

3. Selama proses pembangunan menyebabkan muatan sedimen dalam sungai menjadi lebih besar dan akan berangsur-angsur berkurang sejalan dengan selesainya pembangunan.

4. Kualitas air permukaan umumnya menjadi makin buruk ketika terjadi pembangunan atau perubahan dari kondisi belum terbangun menjadi terbangun.

Perubahan penggunaan lahan dari pertanian/perkebunan, tegalan/hutan menjadi daerah pemukiman akan menyebabkan berkurangnya zona infiltrasi alami. Akibatnya jumlah air hujan yang seharusnya masuk ke dalam tanah menjadi berkurang, sehingga jumlah limpasan permukaan meningkat. Hal semacam ini sering kali terlihat bahwa oleh pengaruh hujan dengan intensitas hujan yang kecil limpasan permukaan besar.

Kondisi seperti ini dimana dengan intensitas hujan kecil akan tetapi limpasan permukaan besar terjadi juga di Jakarta. Aktivitas pembangunan yang sedemikian cepat, berupa pembangunan perkantoran, perumahan dan apartemen, pembangunan sarana dan prasarana umum seperti pusat perbelanjaan, perparkiran, jalan, taman, tempat rekreasi dengan halaman yang diaspal, beton blok, atau dipadatkan, disemen bahkan rawa atau situ berubah fungsi, telah menyebabkan lahan terbuka hijau menjadi berkurang atau hilang.

Jika di atas areal yang sudah dibangun tersebut turun hujan, maka tidak ada ruang bagi air hujan dapat meresap ke dalam tanah. Air hujan segera mengalir lewat atap bangunan, talang air, halaman akan cepat sekali menjadi limpasan permukaan masuk ke dalam saluransaluran air atau selokan dan sungai sebagai runoff.

\subsection{Perumusan Masalah}

Aktivitas pembangunan di berbagai bidang diciptakan untuk dapat membuat hidup manusia menjadi nyaman, aman dan sejahtera, sehingga setiap aktivitas yang dilakukan dapat dijalankan dengan lancar. Berbagai aktivitas tersebut mulai dari kegiatan yang berhubungan dengan transportasi dan komunikasi, termasuk arus barang dan jasa dalam perekonomian. Kelancaran lalu-lintas di jalan raya akan segera berubah menjadi kemacetan ketika hujan mulai turun, genangan air terjadi dimana-mana. Kemacetan lalu-lintas akan menjadi semakin parah jika hujan telah turun lebih dari 1 jam sebab genangan air di jalan bisa mencapai setengah dari ban mobil sedan.

Dampak negatif dari pembangunan dalam kaitannya dengan masalah hidrologi ini tidak boleh dibiarkan berlangsung terus sebab akan menimbulkan berbagai kerugian mulai dari perekonomian, polusi dan penyakit stress. Untuk mencegah dampak yang lebih besar maka diperlukan kebijakan yang tepat, baik bersifat teknis maupun non teknis. Program yang bersifat teknis adalah program yang pelaksanaan kegiatannya menerapkan prinsip-prinsip konservasi, baik melalui cara-cara vegetatif, mekanik dan teknik, sedangkan program yang bersifat non teknis berupa kebijakan hukum, penegakan undang-undang serta sosialisasi yang berupa ajakan simpatik kepada masyarakat.

Pemerintah melalui Kementerian Pekerjaan Umum telah mengeluarkan program kebijakan yang bersifat non teknis, yaitu dengan mengeluarkan program Tata Ruang Wilayah Nasional yang dituangkan dalam Peraturan Pemerintah (PP) No 26 Tahun 2008 tanggal 10 Maret 2008, dimana pada Ayat 1 Pasal 106 mengenai Peraturan zonasi untuk kawasan imbuhan air tanah disusun dengan memperhatikan:

1. pemanfaatan ruang terbuka yang secara terbatas untuk kegiatan budidaya sehingga 
tanah memiliki kemampuan tinggi dalam menahan limpasan air hujan;

2. penyediaan sumur resapan dan/atau waduk sebagai penganti wilayah resapan yang sudah tertutup oleh bangunan; dan

3. penerapan prinsip zero delta $Q$ policy pada setiap kegiatan pembangunan terutama untuk kegiatan pembangunan wilayah yang dimulai pada saat mengajukan ijin membangun.

Prinsip zero delta $Q$ di suatu wilayah dapat dinyatakan gagal jika kemampuan dari kapasitas saluran yang sudah disediakan atau tersedia tidak sesuai lagi dengan kapasitas rancangan atau desain. Ini ditandai dengan besarnya debit aliran langsung yang masuk ke dalam saluran akan tampak lebih besar dibanding dengan debit aliran pada biasanya, padahal debit aliran langsung tersebut dihasilkan oleh curah hujan dengan intensitas yang relatif sama.

Dengan analogi yang sama untuk kejadian di wilayah Jakarta, kegagalan penerapan prinsip zero delta $Q$ dapat dinyatakan sebagai berikut: Jika curah hujan dengan intensitas hujan dengan perioda ulang sama turun diatas wilayah Jakarta dalam kejadian tahun yang berbeda, dampak yang ditimbulkan berbeda meliputi luas genangan dan volume air banjir maka hal ini bukan disebabkan oleh faktor klimatologi. Penyebab perbedaan terletak pada perubahan parameter fisik dari wilayah tersebut. Perubahan parameter fisik wilayah tersebut terutama disebabkan oleh perubahan penggunaan lahan didi wilayah tersebut. Perubahan parameter fisik wilayah tersebut dalam hidrolgi dinyatakan dalam nilai koefisien aliran $(\mathrm{C})$ yang berubah. Oleh karena itu jika dalam suatu wilayah atau daerah aliran sungai turun hujan dengan intensitas hujan sama, luas wilayah sama akan tetapi koefisien aliran $(C)$ berubah semakin besar karena telah terjadi perubahan penggunaan lahan maka debit aliran yang ditimbulkan akan semakin besar dari sebelum berubah. Adanya perbedaan dalam jumlah limpasan/debit (Q) inilah yang seharusnya disikapi oleh semua pihak melalui kebijakan zero delta $Q$ seperti yang dimaksudkan dalam dalam PP No. 26 Tahun 2008, Pasal 106.

\subsection{Tujuan} adalah:

Tujuan dari pembahasan dalam tulisan ini

1. Membicarakan tentang kebijakan zero delta $Q$ terutama untuk mencegah banjir yang lebih buruk lagi yang akan terjadi di Jakarta.

2. Membahas tentang prinsip mencegah banjir.

3. Penerapan kebijakan zero delta $Q$ dalam bentuk penerapan yang dikaitkan dengan permohonan ljin Mendirikan Bangunan
(IMB) dilakukan oleh Pemda DKI terdapat pada SK Gub. DKI No. 68 Tahun 2005.

\subsection{Kerangka Pemikiran}

Konsep zero delta $Q$ policy sudah sering dibahas di berbagai seminar-seminar yang berkaitan dengan sumberdaya air baik yang dilakukan di Departemen Pekerjaan Umum maupun instansi lainnya. Konsep zero delta $Q$ merupakan sebuah konsep yang dikaitkan dengan upaya pengendalian banjir. Dalam penjelasan PP no. 26 tahun 2008, disebutkan bahwa yang dimaksud dengan kebijakan prinsip zero delta $Q$ adalah keharusan bagi setiap pengembang atau pelaku aktivitas pembangunan agar tidak mengakibatkan bertambahnya debit air yang akan masuk ke dalam sistem saluran drainase atau sistem aliran sungai.

Jika mengacu pada PP di atas, penerapan prinsip zero delta $Q$ policy harus menjadi pertimbangan penting dalam penyusunan zonasi kawasan imbuhan air tanah. Lalu, bagaimana dengan yang non-kawasan imbuhan air tanah? Untuk kawasan non imbuhan air tanah seharusnya lebih diperhatikan karena justru pada wilayah ini yang paling banyak mengalami perubahan penggunaan lahan. Pemberian ijin untuk perubahan penggunaan lahan di dalam kawasan non imbuhan air tanah akan lebih mudah di peroleh jika dibanding dengan kawasan imbuhan air tanah.

Akhir-akhir ini alih fungsi kawasan resapan seperti yang terjadi di wilayah puncak menjadi kawasan komersial berupa vila, penginapan atau hotel, dianggap sebagai biang penyebab terjadinya banjir di Jakarta. Jika mengacu pada prinsip zero delta $Q$ policy ini, maka pada kawasan-kawasan komersial tersebut seharusnya sudah diterapkan.

Pada proses penyusunan Amdal (Analisa Dampak Lingkungan), penerapan prinsip ini nampaknya belum menjadi suatu keharusan. Jika penerapan prinsip zero delta $Q$ policy itu berlaku untuk semua kawasan maka tidak akan ada kawasan daratan manapun yang bisa terbebas dari prinsip tersebut. Setiap kawasan daratan mempunyai kontribusi sebagai menyumbang terbentuknya limpasan jika terjadi hujan di atas kawasan tersebut. sehingga zero delta $Q$ dapat diberlakukan.

Pemerintah DKI Jakarta sepertinya selangkah lebih maju dalam menerapkan prinsip zero delta $Q$, hal ini terbukti dengan telah dikeluarkannya peraturan mengenai Pembuatan Sumur Resapan, dengan Surat Keputusan (SK) Gubernur DKI Nomor 68 Tahun 2005. SK tersebut merupakan Perubahan Surat Keputusan Gubernur Provinsi Daerah Khusus Ibukota Nomor 115 Tahun 2001 tentang Pembuatan Sumur Resapan. Berdasarkan peraturan tersebut 
setiap permohonan ljin Mendirikan Bangunan (IMB) wajib membuat Sumur Resapan. Untuk bangunan lama yang sudah ada sebelum tahun 2001 maka diberlakukan kewajiban untuk membuat Dokumen Pemantauan dan Pengelolaan Lingkungan (DPPL). Di dalam dokumen tersebut diuraikan tentang rencana pengelolaan lingkungan, termasuk di dalamnya pembuatan sumur resapan dan pembuatan kolam resapan untuk pengelola lahan dengan luas lahan lebih besar atau sama dengan 5000 $\mathrm{m}^{2}$. Kewajiban pembuatan sumur resapan dan atau kolam resapan merupakan tindakan untuk mengurangi limpasan permukaan dan hal ini sangat sesuai dengan prinsip zero delta $Q$.

Berbagai aktivitas yang dapat dikategorikan dalam prinsip penerapan zero delta $Q$ policy ini, antara lain: menyediakan areal peresapan air hujan, lubang resapan biopori, modifikasi lansekap, penampungan air hujan, rain garden, saluran resapan biopori, sumur injeksi, sumur resapan, dan sebagainya. Jika secara teknik penerapan prinsip zero delta $Q$ policy ini dapat dilakukan dengan cara yang telah disebutkan di atas, maka jumlah limpasan permukaan yang disebabkan oleh curah hujan akan dapat ditekan, dan hal ini sejalan dengan apa yang diharapkan oleh Pemerintah DKI Jakarta.

\section{TINJAUAN TEORI}

Banjir dalam hidrologi dapat didefinisikan sebagai suatu keadaan, dimana debit air sungai melebihi debit aliran dasar (base flow) sebagai akibat dari hujan yang jatuh di atas vegetasi, batuan, permukaan tanah, permukaan air dan saluran sungai. Hujan yang jatuh di atas permukaan tanah sebagian mengalami intersepsi atau langsung jatuh ke permukaan tanah. Air hujan yang jatuh mula-mula akan membasahi tanah, bangunan, batuan dan vegetasi. Berikutnya akan membentuk lapisan tipis air di atas permukaan tanah yang dikenal dengan surface detention, kemudian membentuk aliran linier. Karena ketebalannya bertambah, kecepatan aliran bertambah dan turbulensinya bertambah, maka aliran air menjadi apa yang disebut limpasan permukaan, limpasan permukaan tersebut akhirnya memasuki saluransaluran lalu masuk sungai sebagai aliran sungai.

Tidak semua bagian dari hujan akan menjadi limpasan pada saluran, sebagian darinya mengalami evaporasi, transpirasi oleh tumbuhtumbuhan, evaporasi melalui tanah dan sebagian lagi mengalami infiltrasi. Air hujan yang mengalami infiltrasi ini sebagian ada yang mengalami perkolasi langsung menjadi air tanah, ada yang mengalir menuju dasar sungai tidak sampai mencapai permukaan tanah lebih dahulu, bahkan sebagian air yang mengalami infiltrasi ini tetap tinggal di dalam tanah sebagai lengas tanah.

Limpasan air dalam Daerah Aliran Sungai (DAS) tampak dalam bentuk sistem yang sangat kompleks, terjadi setelah air hujan mengalami perjalanan melalui beberapa tahap mulai dari penimbunan dan pemindahan sampai masuk ke dalam saluran. Kekomplekan ini semakin bertambah sejalan dengan faktor variabel dalam DAS. Variabel dalam DAS yang berkaitan dengan proses hidrologi didalamnya meliputi: a. Variabel Klimatologis, b. Variabel Fisik permukaan lahan, c. Variabel Keluaran, dan d. Variabel proses ${ }^{(8)}$.

Banjir merupakan fenomena alam yang sudah ada sejak dulu. Saat inipun kejadian banjir banyak terjadi di sungai-sungai besar terutama pada daerah-daerah kelokan sungai, dataran banjir dan hilir. Secara umum faktor-faktor penyebab banjir dapat dikelompokkan menjadi dua sebab, yaitu: faktor alam (klimatologis dan fisik) dan faktor manusia.

Faktor alam meliputi faktor iklim, topografi wilayah, jenis tanah, kondisi geologi, geomorfologi, dan penggunaan lahan. Faktor iklim merupakan input, dalam bentuk curah hujan, dipengaruhi oleh intensitas hujan dan lamanya hujan. Faktor topografi memberi kontribusi positip terhadap besarnya aliran jika topografinya atau kelerengan tanah dengan kemiringan tinggi, maka akan dapat memberikan pengaruh yang besar pada aliran. Jenis tanah terutama yang permeabilitas rendah akan memberikan pengaruh yang renda terhadap aliran air. Demikian pula dengan faktor geologi dimana batuan yang keras dengan impermeabilitas tinggi akan memberikan pengaruh yang tinggi terhadap air limpasan.

Faktor geomorfologi berkaitan dengan bentuk bentang alam. Morfologi sungai terdiri dari badan sungai, tanggul alam dan dataran banjir. Faktor penggunaan lahan, perbedaan bentuk penggunaan lahan akan menentukan perbedaan besarnya koefisien aliran (C). Hutan mempunyai koefisien limpasan yang sangat kecil, yaitu $0,01-0,10$, daerah pusat perdagangan, industri, pemukiman apartemen mempunyai C dengan kisaran antara 0,50-0,80, perkotaan 0,500,75 , pemukiman padat $0,40-0,60$, taman, kebun, persawahan 0,20-0,60.

Koefisien aliran adalah nisbah antara besarnya aliran dibanding dengan curah hujan penyebabnya. Koefisien aliran yang semakin kecil maka akan semakin kecil juga air yang akan menjadi aliran, sedangkan koefisien aliran yang semakin besar maka jumlah aliran akan makin besar. Oleh karena itu apabila di suatu wilayah telah mengalami perubahan penggunaan lahan maka jumlah limpasan di wilayah tersebut akan berubah pula. 


\section{UPAYA PENANGGULANGAN BANJIR DI JAKARTA}

Prinsip penerapan konsep kebijakan prinsip zero delta $Q$ adalah adanya pertambahan bangunan seharusnya tidak boleh mengakibatkan bertambahnya debit air ke sistem saluran drainase atau sistem aliran sungai.

Jika mengacu pada Peraturan Pemerintah, penerapan prinsip zero delta $Q$ policy harus menjadi pertimbangan dalam penyusunan zonasi kawasan imbuhan atau daerah tangkapan air hujan, termasuk daerah yang bukan merupakan kawasan imbuhan air tanah. Penerapan konsep zero delta $Q$ seharusnya dapat dilakukan untuk semua persil dari semua jenis penggunaan lahan. Selama ini alih fungsi kawasan resapan menjadi kawasan komersial dipahami sebagai biang penyebab terjadinya banjir. Jika mengacu pada prinsip zero delta $Q$ policy ini, maka harus dapat diterapkan pada kawasan-kawasan komersial.

Pada kawasan yang ditetapkan bukan sebagai kawasan resapan penerapan zero delta $Q$ harus dipahami sebagai kawasan yang menyebabkan atau ikut memicu terjadinya banjir lokal. Dengan adanya pemahaman ini maka penerapan zero delta $Q$ dapat dilakukan baik dikawasan yang telah ditentukan sebagai kawasan resapan maupun pada kawasan bukan merupakan daerah resapan. Secara garis besar penerapan zero delta $Q$ untuk wilayah Jakarta, dapat dimaksudkan sebagai suatu upaya yang mengarah pada cara-cara menanggulangi banjir. Upaya penanggulangan banjir dapat dilakukan dengan langkah sebagai berikut:

1. Mengoptimalkan penampungan air.

2. Penerapan Sumur Resapan.

3. Penataan Lahan yang tepat, Penghijauan.

4. Melakukan normalisasi saluran drainase.

\subsection{Penampungan Air}

Penampungan air seperti waduk dan situ, merupakan alat yang sangat penting dalam rangka mengatur air limpasan yang berasal dari hujan. Sampai saat ini sebagian besar air hujan masih terbuang secara percuma ke laut. Padahal jika musim kemarau, aliran air menjadi kecil, bahkan di beberapa tempat malah terjadi kekurangan air.

Situ-situ di sekitar Jakarta jumlahnya banyak, sebagian berubah fungsi menjadi daerah pertanian dan pemukiman. Situ-situ tersebut dikelilingi oleh pemukiman padat. Kapasitasnya semakin berkurang karena mengalami pendangkalan sampah atau diuruk tanah. Akibat dari kapasitas situ yang semakin turun maka air yang dapat ditampung menjadi berkurang. Pengalihan fungsi situ menyebabkan sebagian air yang biasanya tertampung berpindah ke tempat lain, sehingga sangat potensil menyebabkan banjir.

Pengembalian fungsi situ dan waduk akan bermanfaat untuk mengurangi jumlah air yang masuk ke tubuh sungai, sehingga beban sungai menjadi berkurang sehingga air hujan tidak melimpah ke daerah rawan banjir.

\subsection{Sumur Resapan}

Sumur resapan merupakan salah satu cara konservasi air tanah. Caranya dengan membuat bangunan berupa sumur yang berfungsi untuk memasukkan air hujan ke dalam tanah. Tujuan pembuatan sumur resapan yaitu ${ }^{(5)}$ :

1. Melestarikan dan memperbaiki kualitas lingkungan.

2. Membantu menanggulangi kekurangan air bersih.

3. Membudayakan kesadaran lingkungan.

4. Mengurangi erosi tanah.

Keuntungan yang dapat diperoleh jika melakukan konservasi dengan menggunakan sumur resapan adalah (dengan tambahan) (5) :

1. Mencegah intrusi air laut terutama di dataran pantai.

2. Mereduksi dimensi jaringan drainase, dapat sampai nol jika diperlukan.

3. Menurunkan konsentrasi pencemaran air tanah.

4. Mempertahankan tinggi muka air tanah.

5. Mencegah penurunan kawasan atau land subsidence.

6. Melestarikan teknologi tradisionil sebagai budaya bangsa.

7. Meningkatkan peran serta masyarakat dalam era pembangunan.

8. Membudayakan pola pikir pelestarian lingkungan.

9. Mempunyai resiko pencemaran air tanah yang lebih kecil.

Petunjuk praktis mengenai berapa besarnya volume sumur resapan di wilayah Jakarta diatur dalam SK Gubernur No. 68 Tahun 2005. Yaitu untuk setiap luas atap bangunan $1 \mathrm{~m}^{2}$, maka wajib membuat sumur resapan dengan volume 40 liter. Oleh karena itu jika luas atap bangunan perumahan seluas $100 \mathrm{~m} 2$, maka volume sumur resapan yang harus dibangun volumenya adalah $100 \times 40$ liter yaitu 4.000 It atau $4 \mathrm{~m}^{3}$. Jika lahan yang dimiliki mempunyai luas lebih besar atau sama dengan $5.000 \mathrm{~m}^{2}$, maka diwajibkan membuat kolam resapan yang luasnya adalah $1 \%$ dari luas lahan yang dimilki.

Contoh penerapan sumur resapan di halaman rumah dapat dilihat pada Gambar 3. 


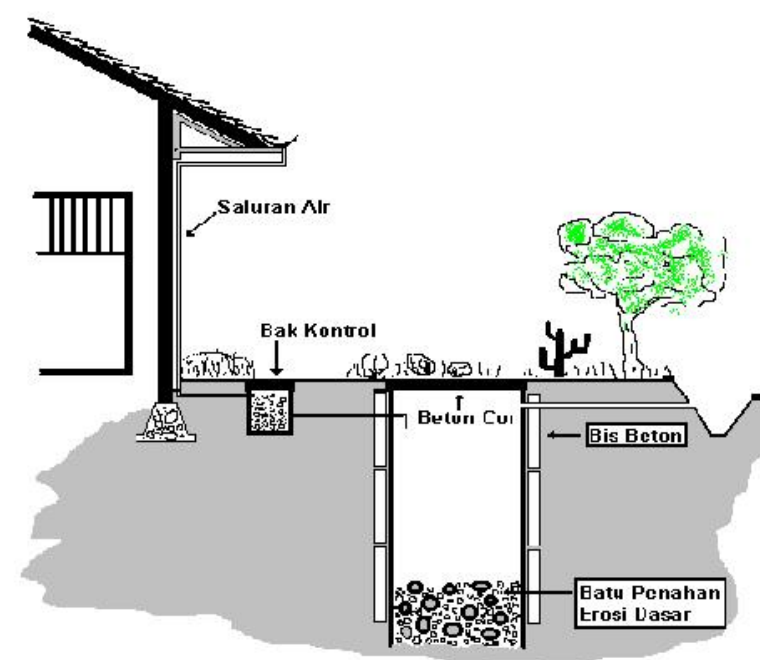

Gambar 3. Penerapan sumur resapan di halaman rumah

Berdasarkan hasil studi yang dilakukan oleh Direktorat Pengkajian Sistem, Badan Pengkajian dan Penerapan Teknologi dalam Studi Model Optimisasi Pengelolaan Air Tanah Jakarta, 1992 , kontrol terhadap intrusi air laut melalui model simulasi dapat dilakukan dengan memberikan imbuhan buatan. Imbuhan buatan pada sistem akuifer dangkal pada daerah seluas $25 \mathrm{~km}^{2}$ berkisar antara 1.082.419 - 54.120.960 $\mathrm{m}^{3} /$ tahun atau antara $1,08-54,12 \mathrm{~m}^{3} /$ tahun $/ \mathrm{m}^{2}(5)$.

Imbuhan buatan tersebut dapat dipenuhi atau dicukupi dengan memanfaatkan sumur resapan.

Berdasarkan Studi tersebut maka dapat dilakukan analisis kebutuhan sumur resapan di Jakarta. Jika dari 1 (satu) buah sumur resapan dengan diameter 0,8 meter, lebar bidang resapan 1 meter pada tanah dengan permeabilitas rendah $(0,00105 \mathrm{~m} /$ hari), maka kapasitas sumur resapan adalah 0,592 $\mathrm{m}^{3} /$ tahun/unit. Dengan demikian untuk daerah Jakarta dan sekitarnya dibutuhkan kurang lebih 2 juta sumur resapan.

Saat ini sedang dimasyarakatkan oleh banyak pihak teknik konservasi air dan tanah dengan memanfaatkan biopori. Biopori adalah membuat lubang-lubang pada permukaan tanah bagian atas dengan menggunakan bor tangan. Alat bor biopori tersebut mempunyak panjang sekitar $120 \mathrm{~cm}$ yang dilengkapi dengan setang bor, batang bor dan mata bor dengan diameter kira-kira 3 inchi dan. Kedalaman lubang berkisar antara $30-50 \mathrm{~cm}$. Lubang biopori berfungsi untuk menampung air hujan dan sebagai tempat untuk membuang sampah organik dari sampah dapur. Sampah organik akan bermanfaat sebagai pupuk organik dan sekaligus sebagai sumber makanan bagi organisme hidup dalam tanah. . Pupuk organik berfungsi untuk menjaga kondisi dan kesuburan tanah dapat terjaga. Disamping untuk menambah kesuburan tanah, organisme yang berkembang dapat membantu menambah lubang-lubang dalam tanah, hal ini akan meningkatkan daya serap tanah terhadap air sehingga air hujan akan semakin mudah meresap ke dalam tanah.

\subsection{Penataan Penggunaan Lahan, Terasering, Bangunan Penahan Air, Penghijauan}

Perubahan penggunaan lahan di suatu wilayah akan berpengaruh pada koefisien limpasan. Penutupan lahan oleh bangunan kedap air akan mempercepat terbentuknya limpasan permukaan. Air hujan yang seharusnya diberikan kesempatan untuk meresap ke dalam tanah, dengan adanya bangunan yang penutup permukaan tanah akan menyebabkan air lebih menjadi limpasan permukaan. Perubahan penggunaan lahan dari lahan perkebunan atau sawah menjadi wilayah pemukiman akan mengurangi zone resapan air.

Pada lahan dengan topografi miring biasanya dibuat berteras-teras, hal ini akan memberikan manfaat terhadap tanah dari limpasan permukaan yang terlalu cepat dan dapat mengurangi erosi tanah. Jika permukaan tanah dibuat berteras-teras maka air hujan akan tertahan dalam teras sehingga aliran air akan lebih lambat sehingga terdapat kesempatan bagi air hujan untuk meresap ke dalam tanah.

Pada umumnya bangunan terasering ini dikombinasi dengan tanaman. Fungsinya untuk melindungi teras agar tidak mudah longsor. Tanaman juga berfungsi untuk menahan erosi karena tetesan air hujan yang jatuh ke atas permukaan tanah, sehingga akan melindungi tanah dari tetesan air hujan. Akar tanaman pelindung teras, bermanfaat untuk menahan dinding teras, dan mebuat lubang-lubang tanah sehingga air hujan akan terserap masuk ke dalam tanah.

\subsection{Normalisasi Drainase}

Tujuan dilakukannya normalisasi drainase adalah untuk memulihkan kemampuan saluran drainase melalui pengerukan atau penurapan tebing sungai agar kapasitas tampung sungai menjadi besar sehingga mampu mengalirkan air yang lebih besar. Kapasitas saluran drainase tersebut seharusnya dirancang dengan mendasarkan hasil evaluasi perhitungan banjir rencana. Untuk mendapatkan rancangan hasil dari banjir rencana secara aman maka dalam mengevaluasi kapasitas drainase dikaitkan dengan rancangan desain dari periode ulang 50 tahun atau 100 tahun.

Jika kapasitas rancangan drainase dibuat untuk desain untuk tingkat keamanan yang tinggi misalnya periode ulang 100 tahun maka konsekuensinya adalah biaya yang dibutuhkan juga akan semakin besar. 


\section{PENUTUP}

Program yang diarahkan untuk penanggulangan banjir di Jakarta haruslah menjadi keinginan yang sungguh dari semua pihak, baik oleh pemerintah maupun masyarakat. Porsi yang menjadi tanggung jawab pemerintah harus dilaksanakan oleh pemeritah sedangkan yang untuk masyarakat harus diserahkan ke masyarakat. Sebagai penutup dari bahasan ini, paling tidak ada empat poin yang cukup riil untuk dapat dilaksanakan yang sangat terkait dengan penerapan kebijaksanaan zero delta $Q$ yaitu:

1. Mengoptimalkan penampungan air.

2. Penerapan sumur resapan atau mengkombinasikan dengan biopori.

3. Penataan lahan yang tepat, menyediakan ruang terbuka hijau yang lebih dari cukup.

4. Melakukan normalisasi drainase, sesuai dengan desain kapasitasnya.

Pemerintah hingga saat ini sudah berupaya untuk mencegah banjir, namun banjir masih tetap berlangsung ketika musim hujan mulai tiba, seperti sudah menjadi agenda tahunan khususya di Jakarta. Mungkin sudah saatnya, peran serta masyarakat harus digalakkan.

Budaya sumur resapan, penggalakan biopori, tidak menggunakan bantaran sungai sebagai tempat-tempat pemukiman, tidak menggunakan sungai sebagai tempat membuang sampah dan menyediakan lahan terbuka hijau.

Khusus untuk sumur resapan, sejalan dengan SK Gub. No 68 Tahun 2005, maka setiap persil bangunan hendaknya menerapkan pembuatan sumur resapan di rumah masingmasing. Jumlah sumur resapan yang dibutuhkan untuk DKI Jakarta berdasarkan hasil simulasi adalah 2 juta sumur resapan agar kondisi muka air tanahnya tetap stabil dan intrusi air laut ke arah darat dapat ditekan.

Jika pemerintah dengan segala kemampuan yang dimilkinya baik tenaga ahli maupun daya kekuatan finansial dikerahkan dengan sungguhsungguh dan masyarakat diberdayakan dengan maksimal, yaitu dengan diberikan suatu penghargaan atas upaya yang sudah dilakukan untuk kepentingan lingkungan hidup maka penerapan zero delta $Q$ sebagai suatu budaya, akan dapat membuat lingkungan terhindar dari banjir. Semoga.

\section{DAFTAR PUSTAKA}

1. http://id.wikipedia.org/wiki/Banjir_Jakarta_ 2007.

2. http://id.wikipedia.org/wiki/Banjir_Jakarta_200 7.

3. Cordery, I. 1976. Evaluation And Improvement of Quality Characteristics of Urban Stormwater. New South Wales, Australia, The University of New South Wales School Of Civil Engineering.

4. Direktorat Pengkajian Sistem. 1992. "Optimisasi, Studi Model Optimisasi Pengelolaan Air Tanah Jakarta". Jakarta. Direktorat Pengkajian Sistem, Kedeputian Bidang Analisis Sistem, Badan Pengkajian dan Penerapan Teknologi.

5. Pemerintah Daerah Khusus Ibukota Jakarta, Brosur, Sumur Resapan Buatan Air Hujan. Jakarta. Dinas Pertambangan DKI.

6. Peraturan Gubernur Provinsi Daerah Khusus Ibukota Jakarta Nomor 68 Tahun 2005 Tentang Perubahan Keputusan Gubernur Provinsi Daerah Khusus Ibikota Jakarta Nomor 115 Tahun 2001 Tentang Pembuatan Sumur Resapan.

7. Peraturan Pemerintah Republik Indonesia Nomor 26 Tahun 2008 Tentang Rencana Tata Ruang Wilayah Nasional.

8. Seyhan, E, 1977, The Watershed As An Hydrologic Unit, Nederland: Publikatie uit het Geografisch Instituut der Rijks Universiteit Utrecht. 